\title{
Pelatihan Pengelolaan Sampah Organik Di Desa Jurumapin Berbasis Kompos Limbah Rumah Tangga
}

\author{
Heri Kusnayadi ${ }^{1 *}$ Siti Nurwahidah ${ }^{2}$, Syahdi Mastar ${ }^{2}$, Nila Wijayanti ${ }^{2}$ \\ ${ }^{1}$ Prodi Agroteknologi Fakultas Pertanian Universitas Samawa \\ ${ }^{2}$ Prodi Agribisnis Fakultas Pertanian Universitas Samawa \\ J1. By Pass Sering Sumbawa Besar Nusa Tenggara Barat \\ "E-mail : kusnayadiheripertanian@gmail.com \\ DOI: https://doi.org/10.21107/pangabdhi.v7i1.9144 \\ Naskah diterima 1 Desember 2020, Revisi 25 Maret 2021, Terbit 29 April 2021
}

\begin{abstract}
The aim of Samawa University, one of which is to provide organic compost training and practice of manufacturing organic fertilizer in the village of Jurumapin, Buer district West Nusa Tenggara. Compost is an organic fertilizer derived from the remains of plants and animal droppings that have been through a decomposition or weathering process. Compost fertilizer is the main ingredient in cow dung. The advantage of this post is green, which may supplement the farmers' income and can increase soil fertility by repairing soil physically damaged by overuse of inorganic fertilizer. The village of Jurumapin was mainly farmers and ranchers. The waste produced by the people's domesticated animals has not been fully processed for fertilizer. Prolonged use of chemical fertilizers can cause physical damage to the soil, as well as the cost of purchasing fertilizer is prohibitive. The implementation of this MTC programme will be by educating them on how organic compost with basic cow dung. The development of organic fertilizer has been carried out with participants who are members of the caduna youth of the mosque of the Jurumapin village. It is hoped that organic compost products could be applied to plants to reduce the use of chemical fertilizer
\end{abstract}

Key Words : organic fertilizer, compost, farmer's income

\section{PENDAHULUAN}

Sampah adalah limbah yang bersifat padat terdiri atas zat organik dan zat anorganik yang dianggap tidak berguna lagi dan harus dikelola agar tidak membahayakan lingkungan dan melindungi investasi pembangunan. Sampah umumnya adalah bentuk sisa makanan (sampah dapur), daun, ranting pohon, kertas/karton, plastik, kain bekas, kaleng-kaleng, debu sisa penyapuan, dan lain sebagainya (SNI 19-24541991 dalam Prayitno, 2009). Sampah adalah limbah yang berbentuk padat dan juga setengah padat, dari bahan organik atau anorganik, baik benda logam maupun benda bukan logam, yang dapat terbakar dan yang tidak dapat terbakar. Bentuk fisik benda-benda tersebut dapat berubah menurut cara pengangkutannya atau cara pengolahannya (Rizaldi, 2008). Sampah adalah sesuatu bahan atau benda padat yang sudah tidak terpakai lagi oleh manusia atau benda padat yang sudah tidak digunakan lagi dan dibuang (Damanhuri, 2006).

Permasalahan sampah merupakan salah satu yang perlu mendapat perhatian yang serius. Sampah dari tahun ke tahun terus meningkat seiring dengan laju pertumbuhan jumlah penduduk. Sampah dapat juga disebut sebagai limbah yaitu hasil produksi dan konsumsi makhluk hidup yang sudah tidak digunakan lagi dan pada akhirnya sebagai sumber pencemaran lingkungan. Limbah dapat berupa bahan organik dan anorganik, kotoran hewan, serasah (gugur daun) dari tanaman atau tanaman yang telah mati. Sedangkan sampah anorganik berupa sisa-sisa industri rumah tangga. Meningkatnya jumlah sampah organik maupun anorganik mengakibatkan berbagai macam permasalahan yang cukup serius.

Produksi sampah di Kabupaten Sumbawa yang dihasilkan oleh 12 Kecamatan mencapai 553.184,90 $\mathrm{m}^{3} /$ tahun. Dari jumlah tersebut Dinas Lingkungan Hidup (LH) Kabupaten Sumbawa hanya bisa mengatasinya 92,881 kubik (Nusra Media, 2019). Kompos merupakan pupuk organik yang berasal dari sisa tanaman dan kotoran hewan yang telah mengalami proses dekomposisi atau pelapukan. Proses pembuatan kompos (komposting) dapat dilakukan dengan cara aerobik maupun anaerobik. Proses pengomposan adalah proses menurunkan $\mathrm{C} / \mathrm{N}$ bahan organik hingga sama dengan $\mathrm{C} / \mathrm{N}$ tanah. Keunggulan dari pupuk kompos adalah ramah lingkung,an, dapat 
menambah pendapatan peternak dan dapat meningkatkan kesuburan tanah dengan memperbaiki kerusakan fisik tanah akibat pemakaian pupuk anorganik (kimia) secara berlebihan (Subekti, 2015).

Salah satu limbah oganik hasil rumah tangga adalah limbah sayur, buah-buahan busuk dan sisa makanan. Limbah hasil rumah tangga ini dapat digunakan sebagai bahan baku pembuatankompos organis berbasis kotoran ternak. Tujuan diadakannya program pelatihan pembuatan kompos ini, karena tingginya minat masyarakat terhadap kompos organik dan cara pemanfaatan kotoran hewan ternak. Sumber bahan pupuk kompos antara lain berasal dari limbah organik seperti sisa-sisa tanaman (jerami, batang, dahan), sampah rumah tangga, kotoran ternak (sapi, kambing, ayam, itik), arang sekam, abu dapur dan lain-lain (Rukmana, 2007).

\section{METODE}

\section{Lokasi dan Partisipan Kegiatan}

Kegiatan Kuliah Kerja Nyata Pembelajaran ini telah dilakukan di Desa Jurumapin Kecamatan Buer Kabupaten Sumbawa dan dilaksanakan bulan Juni-Juli 2020. Partisipan pada kegiatan ini adalah masyarakat Desa Jurumapin dan merupakan anggota kelompok Bank Sampah Desa Jurumapin sejumlah 30 orang.

\section{Bahan dan Alat}

Bahan yang telah digunakan berupa kotoran limbah rumah tangga, MA 11, sersah daun bambu, sekam padi, abu sisa pembakaran kayu, air, garam, buah-buahan busuk, kotoran sapi. Alat yang telah digunakan berupa terpal, cangkul, plastik, sekop, termometer.

\section{Pelaksanaan Kegiatan}

Metode yang telah digunakan dalam dalam pelaksanaan kegiatan pelatihan ini adalah metode partispasi aktif yaitu metode dengan melibatkan masyarakat dan peserta dalam pelaksanaan kegiatan pelatihan secara aktif dari awal sampai akhir. Pengumpulan data menggunakan metode wawancara secara langsung kepada peserta dengan menggunakan kuisioner yang berisi pertanyaan-pertanyaan untuk melihat kemampuan peserta sebelum dan sesudah pelaksanaan kegiatan

\section{HASIL DAN PEMBAHASAN \\ Pelaksanaan Kegiatan}

Penyampaian materi tentang kompos. Kompos merupakan pupuk alami (organik) yang dapat di buat dari bahan-bahan hijau dan bahan organik lainnya yang ditambahkan dengan sengaja sehingga proses dekomposisi akan lebih cepat. Hasil dekomposisi bahan-bahan organik seperti kotoran ternak dan limbah rumah tangga, tanaman, dan limbah organik lainnya menghasilkan kompos yang dimanfaatkan untuk memperbaiki struktur tanah, memperbaiki kehidupan mikrorganisme dalam tanah, menambah daya ikat air terhadap tanah, dan memperbaiki sifat-sifat tanah lainnya. Gambar proses penyampaian materi kepada peserta sebagai berikut :
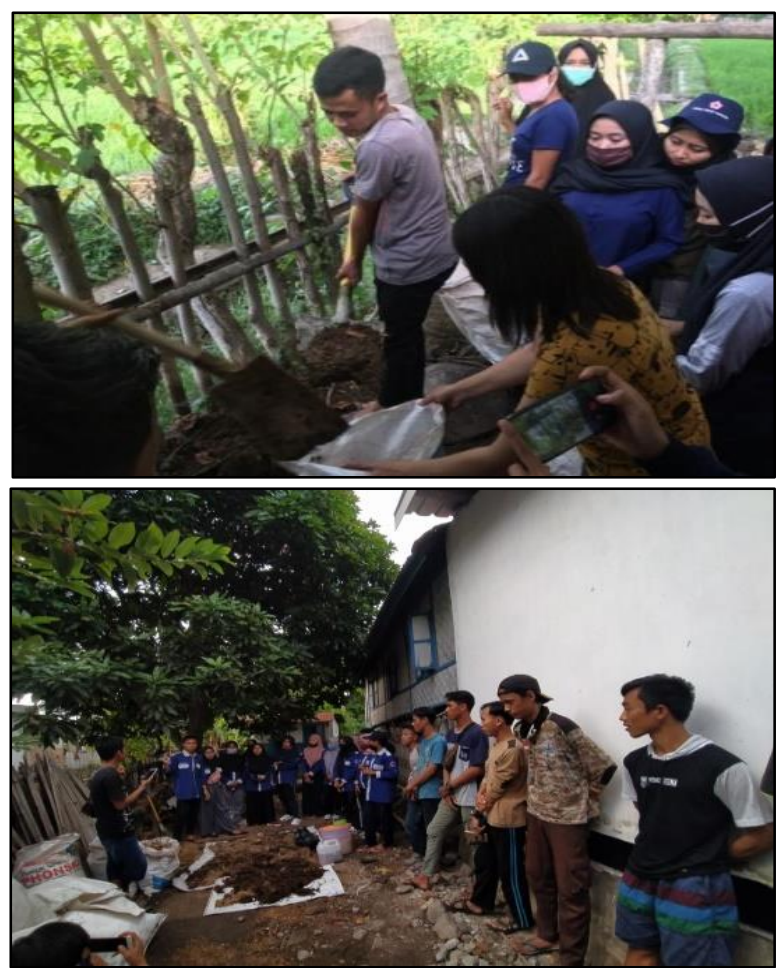

Gambar 1. Proses Pelatihan Pemberian Materi Teknik Pembuatan Kompos

Manfaat kompos adalah dapat meningkatkan kesuburan tanah, membantu memperbaiki karakteristrik dan struktur tanah, meningkatkan aktifitas mikroba pada tanah, meningkatkan daya serap air tanah, meningkatkan kualitas hasil panen, menyediakan unsur hara pada tanah, membuat tanah menjadi lebih gembur dan tidak keras, menekan pertumbuhan penyakit tanaman, menyediakan vitamin dan hormon yang dibutuhkan oleh tanaman (Setyorini, 2003).

Fungsi bahan pembuatan kompos organik yaitu MA 11, berfungsi sebagai bahan aktif mikroba dan pengurai kompos yang dilarutkan 
dalam air, takarannya 1 liter MA 11 dilarutkan dengan 6 liter air (1:6). Biang garam berfungsi untuk membunuh mikroba yang tidak diinginkan dalam kompos tersebut, bahan yang terdapat dalam biang garam tersebut yaitu larutan garam, buah-buahan busuk dan daun-daun hijau tidak bergetah. Seresah bambu berfungsi untuk memperbaiki struktur tanah karena mengandung unsur hara $\mathrm{N}$ dan $\mathrm{P}$. Serasah daun bambu mengandung banyak unsur P dan K. Kedua unsur ini sangat berguna bagi perbaikan struktur tanah dan bagi pertumbuhan tanaman.

Petani Dukuh Waru, Desa Pengkol, Kecamatan Karanggede, Kabupaten Boyolali, Jawa Tengah telah mencoba di lahannya sendiri dengan menambahkan serasah daun bambu ke lahan sawah, maka tidak perlu lagi menggunakan pupuk P dan K. Dengan demikian petani tersebut tidak lagi menggunakan pupuk kimia setelah memakai pupuk kompos ditambah dengan serasah daun bambu (Sutoyo 2003). Sekam padi dapat membantu menggemburkan tanah hingga bisa mempermudah akar tanaman menyerap unsur hara didalamnya. Abu sisa pembakaran kayu sebagai bahan aktif untuk mempercepat pertumbuhan tanaman. Kotoran ternak sebagai bahan yang mengandung unsur hara tinggi berupa NPK yang sangat baik untuk pertumbuhan tanaman. Adapun gambar bahan-bahan yang telah digunakan selama pelatihan disajikan sebagai berikut:

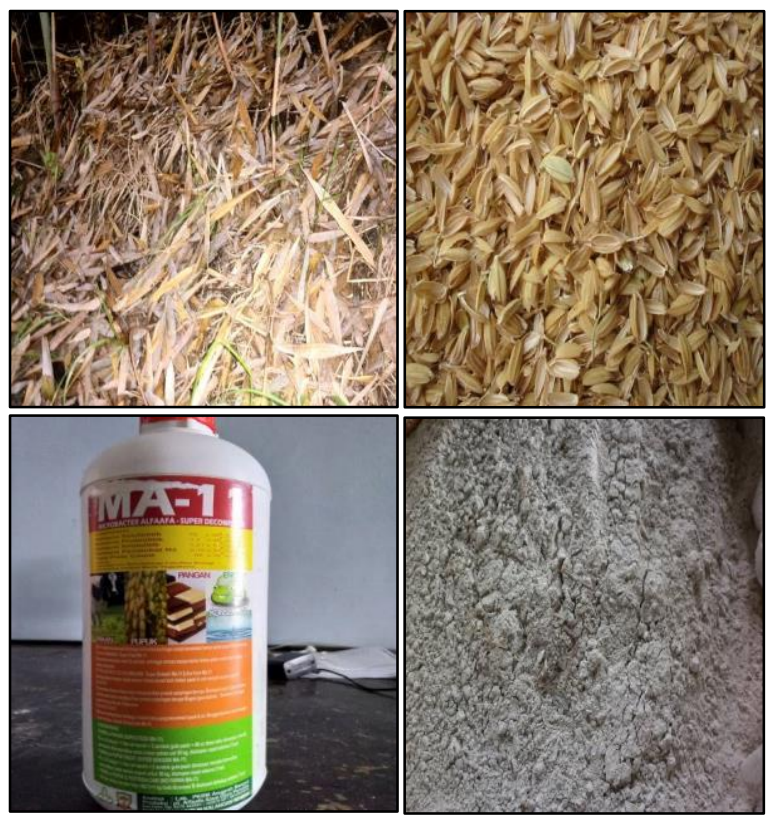

Gambar 2. Bahan-Bahan yang Digunakan Pada Pelatihan Teknik Pembuatan Kompos

Pelatihan pembuatan kompos diawali dengan penyiapan bahan baku (kotoran ternak, serasah daun bambu, MA 11, sekam padi, abu sisa pembakaran kayu). Alat yang digunakan seperti sekop, cangkul, terpal, plastik dan termometer. Adapun gambar produk kompos yang telah dihasilkan dari kegiatan pelatihan ini adalah sebagai berikut :
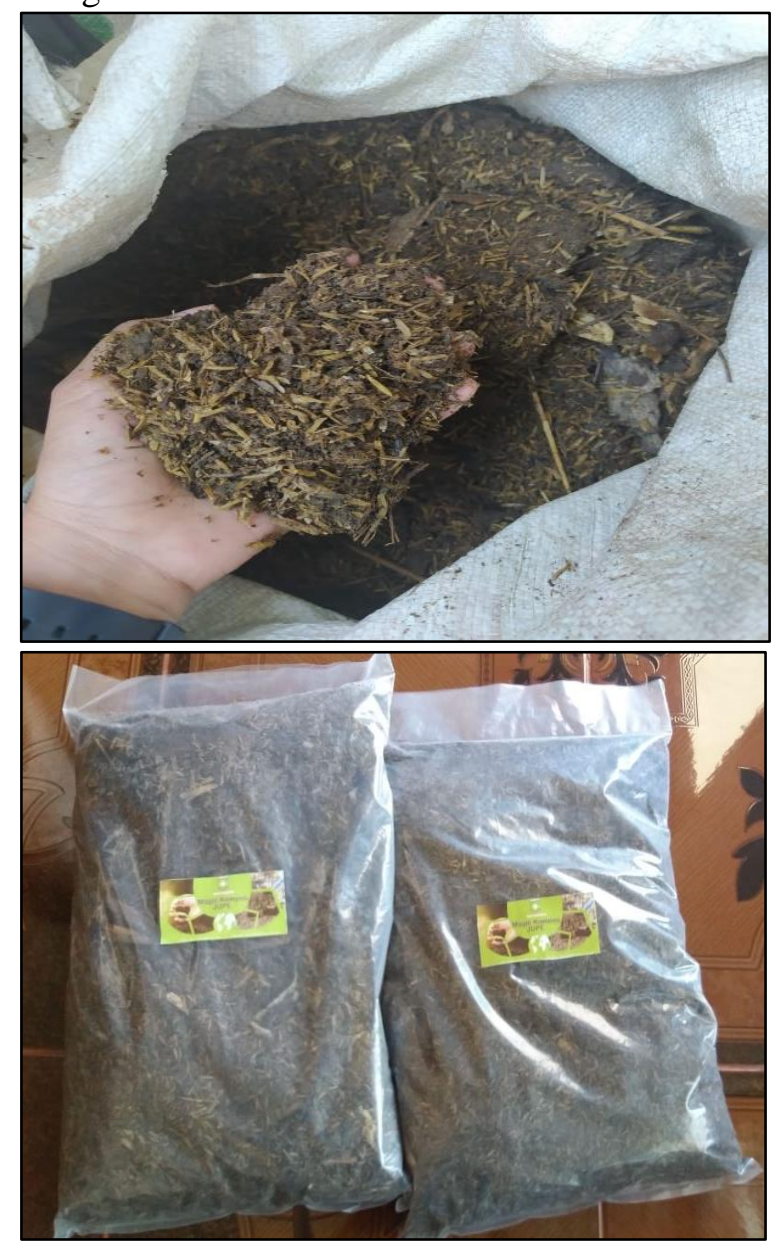

Gambar 3. Kompos Hasil dari Kegiatan Pelatihan

\section{Kendala Kegiatan}

Kendala yang dihadapi dalam pembuatan kompos organik, bahan baku berupa kotoran ternak yang basah, untuk proses pencacah harus dalam keadaan kering. Kendala lainnya adalah pembuatan starter yang belum maksimal karena memerlukan tingkat ketelitian tinggi.

\section{Dampak Kegiatan}

Dampak adanya pelatihan pembuatan kompos berbasis kotoran ternak di desa Jurumapin adalah mengurangi limbah sampah organik yang selama ini dibuang dan memberikan dampak kurang baik bagi lingkungan serta pembakaran sampah organik yang menimbulkan polusi udara. Limbah kotoran ternak yang awalnya menjadi salah satu limbah di lingkungan masyarakat, setelah adanya pelatihan ini masyarakat dapat memanfaatkan 
limbah kotoran ternak tersebut sebagai bahan baku pembuatan kompos organik.

\section{KESIMPULAN}

Kesimpulan dari program kegiatan pengabdian masyarakat ini adalah bahwa masyarakat Desa Jurumapin antusias terhadap program KKN PPM, dalam hal ini pembuatan pupuk organik dari kotoran ternak untuk diaplikasikan di tanaman. Praktek pembuatan pupuk organik telah dilaksanakan dan berhasil dengan baik. Selanjutnya petani dapat secara mandiri melakukan proses pembuatan pupuk organik. Adanya pupuk organik ini dapat mengurangi penggunaan pupuk an-organik. Selain itu dengan adanya teknologi ini masyarakat dapat menghemat biaya yang dikeluarkan untuk pembelian pembelian pupuk serta dapat memelihara kesuburan tanah.

\section{DAFTAR PUSTAKA}

Damanhuri, E \& Padmi, T. 2006. Sampah, Diktat Kuliah TL-3150/ITB, Bandung.

Prayitno, E. 2009. Pengelolaan Sampah Berbasis Masyarakat, Tesis teknik lingkungan Universitas Pasundan, Bandung.
Prihandini, P.W \& Purwanto, T. 2007. Petunjuk Teknis Pembuatan Kompos Berbahan Kotoran Sapi. Pusat Penelitian dan Pengembangan Peternakan, Depertemen Pertanian.

Rizaldi, R. 2008. PengelolaanSampah Secara Terpadu Di Perumahan Dayu Permai Yogyakarta, Tugas Akhir Jurusan Teknik Lingkungan Universitas Islam Indonesia, Yogyakarta

Rukmana, R. 2007. Bertanam Petsai dan Sawi. Kanisius. Yogyakarta.

Siregar, S. 2005. Statistik Terapan Untuk Penelitian. Jakarta: PT. Gramedia

Setyorini D. 2003 Persyaratan mutu pupuk organik untuk menunjang budidaya pertanian organik. Disampaikan pada seminar sehari. Penggunaan pupuk organik. BPTP. Di Yogyakarta

Subekti, K. (2015). Pembuatan kompos dari kotoran sapi (komposting). Fakultas Teknologi Pertanian, Universitas Gadjah Mada, Yogyakarta

Sutoyo. 2003. Daun Bambu pun Pindah ke Sawah. Salam 3: 13- 15. 